\title{
Effect of high concentrations of glucose on differentiation of rat trophoblast cells in vitro
}

\author{
L. Hinck ${ }^{1}$, J. P. Thissen ${ }^{2}$, S. Pampfer ${ }^{1}$, R. Hertogh ${ }^{1,3}$ \\ ${ }^{1}$ Physiology of Human Reproduction Research Unit, Catholic University of Louvain Medical School, Brussels, Belgium \\ 2 Diabetes and Nutrition Unit, Catholic University of Louvain Medical School, Brussels, Belgium \\ ${ }^{3}$ Diabetes and Nutrition Unit, UCL/DIAB 5474, Brussels, Belgium
}

\section{Abstract}

Aims/hypothesis. Previous studies have shown that diabetic placentas are characterized by structural and biochemical anomalies, including defects in the differentiation of trophoblasts. In this study, the Rcho- 1 cell line was used to investigate the impact of high glucose concentrations on different markers of differentiation of rat trophoblast cells in giant cells (endoreduplication, invasive phenotype and endocrine phenotype).

Materials. Rcho- 1 cells were incubated for 12 days in medium supplemented with different concentrations of glucose and $10 \%$ horse serum to optimize differentiation. The cells were examined for the proportion of nuclei showing signs of apoptosis. The effect of high glucose was investigated on the endoreduplication process, on invasive phenotype (secretion of gelatinase B) and on endocrine phenotype (expression of placental lactogen I (PL-I) and II (PL-II) and progesterone secretion).

Results. Apoptosis was not induced by high glucose in Rcho-1. The number of cells was higher in the cul- tures exposed to high glucose $(p<0.05)$ and their nuclei contained more DNA compared with control cells $(p<0.001)$, while their nuclear size was smaller $(p<0.001)$. Gelatinase B secretion increased during differentiation but no difference was found when gelatinase B secretion from trophoblasts exposed to high glucose was compared with the control cells. Rcho-1 cell cultures showed an increase in PL-I and PL-II mRNA expressions during differentiation and which was not affected by high glucose. Progesterone secretion increased during differentiation in control cultures. However, this increase was abolished when trophoblasts were cultured in high glucose.

Conclusions/interpretation. Our data suggest that high glucose influences the endoreduplication process and the steroidogenesis during differentiation of rat trophoblasts. [Diabetologia (2003) 46:276-283]

Keywords Trophoblast, giant cells, high glucose, diabetes, differentiation, endoreduplication, invasive phenotype, endocrine phenotype.
The trophectoderm (TE) is the first tissue to differentiate in the mammalian embryo. It forms a monolayer surrounding the inner cell mass (ICM) and the blasto-

Received: 10 June 2002 / Revised: 8 August 2002

Published online: 5 February 2003

C Springer-Verlag 2003

Corresponding author: R. De Hertogh, Diabetes and Nutrition Unit, UCL/DIAB 5474, Av. Hippocrate, 54, 1200 Brussels, Belgium

E-mail: dehertogh@obst.ucl.ac.be

Abbreviations: ICM, inner cell mass; TE, trophectoderm; PL-I, placental lactogen-I; PL-II, placental lactogen-II. coelic cavity at the blastocyst stage of the development. The TE consists of two regions: the polar trophectoderm, directly adjacent to the ICM and the mural trophectoderm surrounding the blastocoelic cavity. In the rodent placenta, the cells of the mural TE transform into a limited number of non-dividing primary giant cells during implantation whereas those of the polar TE proliferate into the ectoplacental cone and develop a multitude of secondary giant cells [1]. The primary and the secondary giant cells are morphologically indistinguishable and are formed through a process referred to as endoreduplication, continued DNA replication without concomitant cell division [2, 3]. 
During the differentiation, trophoblast giant cells acquire a number of specialized functions, including the potential for invasion and the biosynthesis of steroid and polypeptide hormones, the endocrine activity [4, $5,6]$. Development of the trophoblast cell lineage is essential for the establishment and maintenance of an effective exchange pathway between maternal and foetal tissues during pregnancy.

Although important morphological and developmental differences exist between the placentas of primates and rodents, structural and biochemical abnormalities have been observed in placentas derived from diabetic pregnancies of both humans and rodents. These placentas are characterized by placentomegaly and delayed maturation during late gestation [7, 8]. A number of studies suggest that the placental development in diabetic pregnancies is already impaired at the early stages, even before anomalous organogenesis can be observed $[9,10,11]$. The in vitro outgrowth of the trophoblast of blastocysts from diabetic rats is limited compared with the outgrowth of control blastocysts. Moreover, the frequency of giant cells is abnormally high in outgrowths formed in vitro by blastocysts from either genetically prone diabetic rats or drug-induced diabetic rats $[11,12]$. These observations support the conclusion that diabetes disturbs the differentiation of trophoblasts.

In this study, Rcho-1 cell line was used to investigate the effect of high glucose concentrations on different markers of differentiation of trophoblast cells in giant cells. The Rcho-1 trophoblast cell line can be maintained in a proliferative state or induced to differentiate into trophoblast giant cells that morphologically and functionally resemble trophoblast giant cells developing in situ $[13,14]$.

\section{Materials and methods}

Rcho-1 trophoblast cell culture. The Rcho-1 trophoblast cell line was derived from a rat choriocarcinoma and is capable of differentiation along the trophoblast giant cell lineage (Fig. 1). Rcho-1 trophoblast cells were routinely maintained in subconfluent conditions with NCTC-135 culture medium (Sigma Chemicals; St. Louis, Mo., USA) supplemented with $20 \%$ FBS (Life Technologies; Paisley, UK), $10 \mathrm{mmol} / \mathrm{l}$ hydroxyethylpiperazine ethanesulfonic acid (Hepes), $50 \mu \mathrm{mol} / 1 \beta$-mercaptoethanol, $1 \mathrm{mmol} / \mathrm{l}$ sodium pyruvate, $2 \mathrm{mmol} / \mathrm{l}$ glutamine, $100 \mathrm{U} / \mathrm{ml}$ of penicillin and $100 \mu \mathrm{g} / \mathrm{ml}$ of streptomycin in a humidified incubator under $5 \% \mathrm{CO}_{2} / 95 \%$ air at $37^{\circ} \mathrm{C}$. Differentiation was induced by growing the cells to confluence in FBS supplemented culture medium and then replacing the serum supplementation with $10 \%$ HS (Horse serum) (Life technologies) (day 0 of culture). During induction of differentiation, glucose concentration in the culture medium with $10 \%$ HS was either $6 \mathrm{mmol} / \mathrm{l} \mathrm{D}$-glucose $(6 \mathrm{mmol} / \mathrm{l} \mathrm{D}-\mathrm{G})$ or $28 \mathrm{mmol} / \mathrm{l}$ D-glucose $(28 \mathrm{mmol} / \mathrm{l} \mathrm{D}-\mathrm{G})$; the osmolarity control medium was $6 \mathrm{mmol} / \mathrm{l} \mathrm{D}$-glucose and $22 \mathrm{mmol} / \mathrm{l} \mathrm{L-glucose}(28 \mathrm{mmol} /$ $1 \mathrm{D}+\mathrm{L}-\mathrm{G})$.

Determination of apoptosis and mitotic index. Incidence of chromatin degradation and nuclear fragmentation, two nuclear

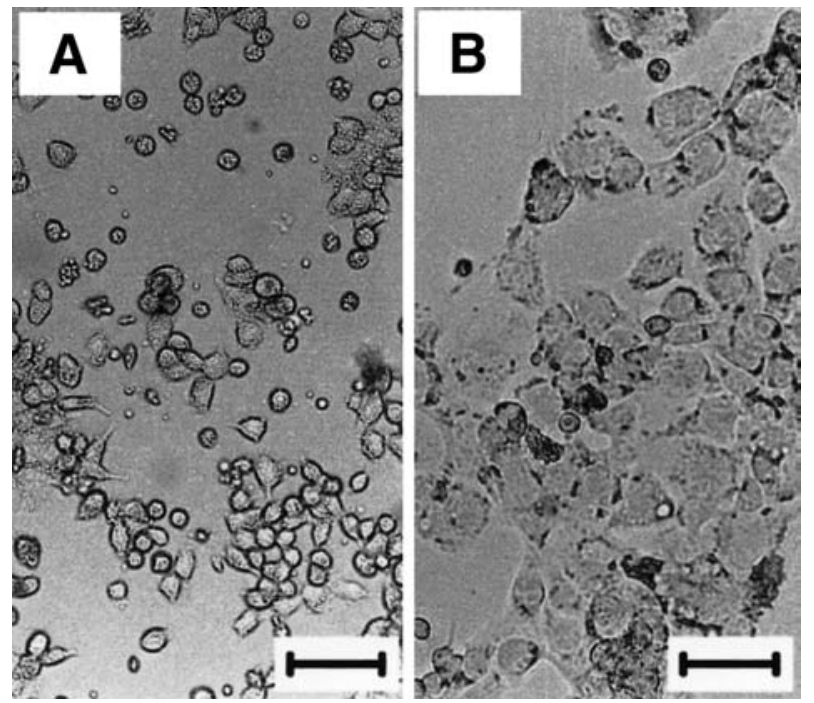

Fig. 1A, B. Morphology of Rcho-1 trophoblast cells at different stages. (A) growth phase, containing predominantly stem cells; (B) differentiation phase, containing predominantly giant cells. Scale bar represents $50 \mu \mathrm{m}$

markers of apoptosis, were analyzed by terminal transferasemediated dUTP nick end labelling (TUNEL) coupled with bisbenzimide-staining. The Rcho- 1 cells were fixed in $4 \%$ paraformaldehyde, treated with $0.3 \%$ hydrogen peroxide, permeabilized in $0.1 \%$ Triton X-100, prestained in $25 \mu \mathrm{g} / \mathrm{ml}$ bisbenzimide, and then incubated with $50 \mathrm{U} / \mathrm{ml}$ of terminal transferase (Roche Diagnostics-Boehringer, Mannheim, Germany) and $15 \mu \mathrm{mol} / 1$ fluorescein-conjugated dUTP for $35 \mathrm{~min}$ at $37^{\circ} \mathrm{C}$ in a specific reaction buffer. Following exposure to a sheep antifluorescein antibody conjugated to peroxidase for $30 \mathrm{~min}$ at room temperature, TUNEL staining was developed in a solution of diaminobenzidine and nickel chloride. Each culture was examined under combined UV and visible lights for cells with chromatin degradation (positive TUNEL staining), nuclear fragmentation (densely bisbenzimide stained cluster of nuclear material) or mitosis (a typical metaphasis figure). We tested five series of Rcho-1 cultures independently for each experimental condition. Data were expressed as percentages (means \pm SEM) of cells displaying either one of these two nuclear markers relative to the total number of cells counted per culture.

Measurement of cell number and nuclear size. The cells were fixed for $20 \mathrm{~min}$ in cold $\left(-20^{\circ} \mathrm{C}\right) 70 \%$ ethanol. The nucleus of the cells were stained with bisbenzimide $(25 \mu \mathrm{g} / \mathrm{ml})$ and counted under microscope in an area of $5 \mu \mathrm{m}^{2}$. Each experiment was carried out five separate times for each experimental condition.

The nuclear size was measured with Scion-modified NIH image program (version 1.62) after acquisition of the image. The nuclear image of about 150 cells on three slides was analyzed per experimental condition.

Feulgen staining. The DNA content per nucleus was estimated with the Feulgen reaction because it allows selective and quantitative (stoichiometric) staining of the DNA. The cells were fixed for $15 \mathrm{~min}$ in a 70:25:5 mixture of 96\% ethanol, formaldehyde and acetic acid. The formaldehyde was neutralized by means of a satured $\mathrm{K}_{2} \mathrm{HPO} 4$ solution. The slides were then stored at $4^{\circ} \mathrm{C}$ until staining. All the slides were stained together for $1 \mathrm{~h}$ in Feulgen reagent (Fluka, St Louis, Mo., USA) after hydrolysis in $6 \mathrm{~mol} / \mathrm{l} \mathrm{HCl}$ for $1 \mathrm{~h}$ at room temperature. 
Morphonuclear assessments were done by means of a Samba 2005 (AlcatelTITN, Grenoble, France) microscope image processor. The system allows 15 parameters to be described quantitatively. These parameters relate to morphometric (nuclear size), densitometric (nuclear DNA content) and textural (chromatin heterogeneity, distribution and organization) features. Of these parameters three were used in this study: the nucleus area, a morphometric parameter which corresponds to the area of the nuclear profile (the number of pixels occupied by the nucleus); the integrated optical density, a densitometric parameter which is related to the total DNA content (the sum of the optical density values of each pixel) and one textural parameter which is representative of the overall condensation level of the chromatin (the local mean of the cooccurrence matrix). We analyzed five Feulgen-stained slides per experimental condition and the nuclear images of about 400 to 500 cells were analyzed per slide.

Substrate gel electrophoresis (zymography). Metalloproteases in medium conditioned by the Rcho- 1 trophoblast cell was determined by gelatin-substrate zymography. Rcho- 1 trophoblast cells were seeded at 33333 cells per $\mathrm{cm}^{2}$ in NCTC-135 containing $20 \% \mathrm{FBS}$ and incubated at $37^{\circ} \mathrm{C}$ until confluence. The dishes were washed with Hank's balanced salt solution (HBSS) and changed, to promote differentiation, to NCTC-135 with $10 \%$ HS containing different concentrations of glucose. After various stages of trophoblast differentiation, the cultures were maintained in a serum-free medium for $18 \mathrm{~h}$ and the conditioned medium was collected. Conditioned medium was mixed with SDS-PAGE nonreducing buffer (40\% glycerol, 250 mmol/1 TRIS-HCl (pH 6.8) 6\% SDS, 0.005\% bromophenol blue) and loaded on $8 \%$ polyacrylamide gels, copolymerized with gelatin (Sigma Chemicals) at $0.5 \mathrm{mg} / \mathrm{ml}$. After electrophoresis, SDS had been removed by rinsing with $2.5 \%$ Triton X-100 and the gel was incubated for $18 \mathrm{~h}$ at $35^{\circ} \mathrm{C}$ in a zymography incubation buffer ( $50 \mathrm{mmol} / \mathrm{l}$ TRIS-HCl (pH 7.5),

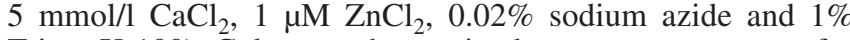
Triton X-100). Gels were then stained at room temperature for 30 min in Coomassie brilliant blue R-250 solution [45\% methanol, 9\% acetic acid and $0.25 \%$ in Coomassie brilliant blue R-250 (Sigma Chemicals)] and destained in destain solution (20\% methanol, 7\% acetic acid, 20\% Norvanol). Proteolysis was detected as clear bands in a dark field. For gelatinase B expression analysis, the intensity of the proteolysis bands was quantified by computer-assisted scanning and densitometry with normalization to the same sample in the different gels. Each experiment was carried out three times.

Northern blot analysis. Expression of placental lactogen-I (PL-I) and placental lactogen II (PL-II) RNA was evaluated by Northern blot analysis. Total RNA was isolated at the indicated times of differentiation using Tri-Reagent (Sigma Chemicals). The RNA concentration was calculated from the absorption at $260 \mathrm{~nm}$ and $20 \mu \mathrm{g}$ from each sample were fractionated on a $1 \%$ agarose-formaldehyde gel. The RNA was transferred to a nylon membrane, Hybond-N (Amersham, Bucks., UK) and fixed in place by UV cross-linking. The membrane was then hybridized to probes derived from random-primed synthesis using High Prime (Boehringer Mannheim) and ${ }^{32} \mathrm{P}$ dCTP (Amersham). The blot was then exposed to Kodak Biomax-MS film (Sigma Chemicals). The cDNA inserts of PL-I and PL-II used as templates for the synthesis of DNA probes were provided by Dr. Soares (University of Kansas, Kansas City, USA) [15].

For PL-I and PL-II RNA expression analysis, the intensity of the hybridization bands was quantified by computer-assisted scanning and densitometry. Each experiment was done three times.
Steroid radioimmunoassays. Progesterone concentration in the conditioned medium was measured by radioimmunoassay (Immunotech, Marseille, France) and normalized to cell number. The conditioned media were collected every 2 days during 12 days and each experiment was carried out three times.

Statistical analysis. The data are expressed as mean values \pm SEM. Data were analyzed with one-way analysis of variance (ANOVA) coupled to post hoc Fisher's test. A $p$ value of 0.05 was considered statistically significant.

\section{Results}

Apoptotic effect of high glucose on trophoblast differentiation. Rcho-1 cells were examined for the proportion of nuclei showing signs of chromatin degradation or nuclear fragmentation, two nuclear markers of apoptosis, after incubation in $6 \mathrm{mmol} / \mathrm{l} \mathrm{D}-\mathrm{G}$, $28 \mathrm{mmol} / \mathrm{l} \mathrm{D}-\mathrm{G}$ or $28 \mathrm{mmol} / \mathrm{l} \mathrm{D}+\mathrm{L}-\mathrm{G}$. Staining was done every 3 days for 12 days, to detect cells showing signs of nuclear fragmentation (bisbenzimide staining) or chromatin degradation (TUNEL staining). Chromatin degradation was below $1 \%$ and nuclear fragmentation below $2 \%$ in the different groups, indicating the absence of apoptosis induction by high glucose in differentiating Rcho-1 cultures.

Effect of high glucose on cell number, mitotic index and nuclear size. After the shift of medium to optimize the differentiation (day 0), Rcho-1 cell number per unit surface area showed a gradual decline (Fig. 2A). This decrease was more important in the control media (6 mmol/l $\mathrm{D}-\mathrm{G}$ and $28 \mathrm{mmol} / \mathrm{l} \mathrm{D}+\mathrm{L}-\mathrm{G})$ compared to a medium with a high glucose concentration $(28 \mathrm{mmol} / \mathrm{l} \mathrm{D}-\mathrm{G})(p<0.05)$.

The frequency of mitotic figures in differentiating Rcho-1 cultures (Fig. 2B) was below 1\%, indicating the absence of cell proliferation.

The nuclear size in differentiating trophoblast cells is depicted in Fig. 2C. The nucleus area increased during differentiation. This increase was more important in the control cells $(6 \mathrm{mmol} / \mathrm{l} \mathrm{D}-\mathrm{G}$ and $28 \mathrm{mmol} / \mathrm{l} \mathrm{D}+\mathrm{L}-\mathrm{G})$ compared with the cells exposed to high concentration of glucose $(28 \mathrm{mmol} / \mathrm{l} \mathrm{D}-\mathrm{G})$ $(p<0.05)$.

The absence of mitosis and the increase of the nuclear size suggested that Rcho-1 cells were undergoing endoreduplication.

Effect of high glucose on the endoreduplication process. The Rcho-1 giant cells were analyzed for DNA content at day 12 of differentiation with the Feulgen reaction, which allows a selective and quantitative staining of the DNA. The spectrophotometric results indicated that the DNA content per nucleus was increased after 12 days of differentiation. Nuclei from cells exposed to high glucose concentration 

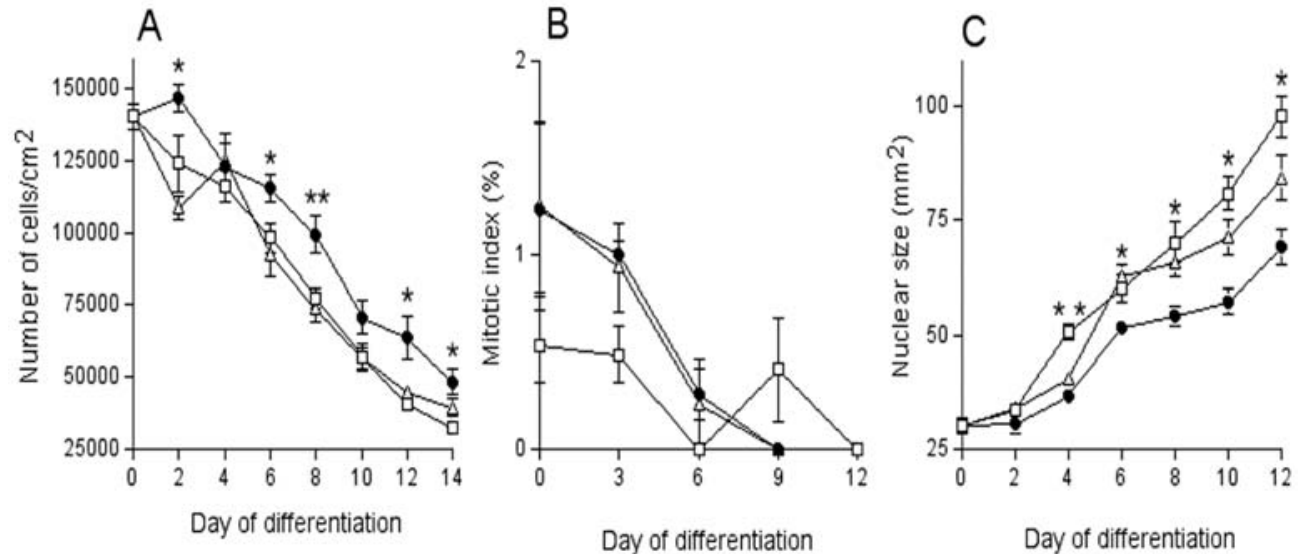

Fig. 2A-C. Effect of different concentrations of glucose on number of cells $(\mathbf{A})$, mitotic index $(\mathbf{B})$ and nuclear size $(\mathbf{C})$ ( $\square 6 \mathrm{mmol} / \mathrm{l} \mathrm{D}-\mathrm{G} ; 28 \mathrm{mmol} / \mathrm{l} \mathrm{D}-\mathrm{G} ; \triangle 28 \mathrm{mmol} / \mathrm{l} \mathrm{D}+\mathrm{L}-\mathrm{G})$. (means \pm SEM of five independent experiments) $(* p<0.05$; ** $p<0.01$ vs $6 \mathrm{mmol} / \mathrm{l} \mathrm{D}-\mathrm{G})$
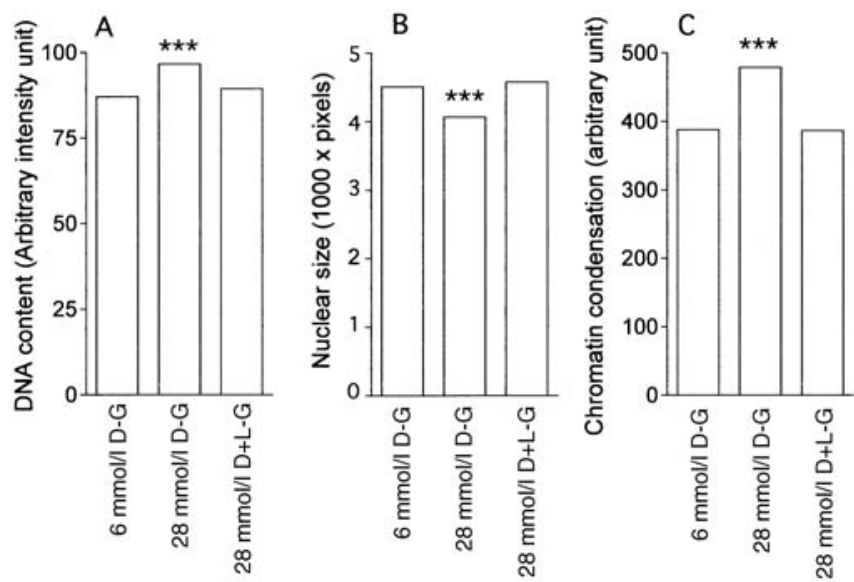

Fig. 3A-C. Effect of different concentrations of glucose on the endoreduplication process. Three morphonuclear parameters were analyzed on day 12: DNA content $(\mathbf{A})$, nuclear size $(\mathbf{B})$ and chromatin condensation $(\mathbf{C})$. (means \pm SEM of five independent experiments) $(* * * p<0.001$ vs $6 \mathrm{mmol} / \mathrm{l} \mathrm{D}-\mathrm{G})$

A

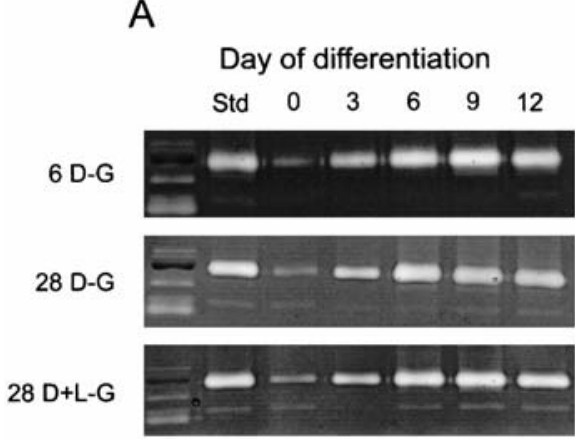

Gelatinase B

Gelatinase B

Gelatinase B

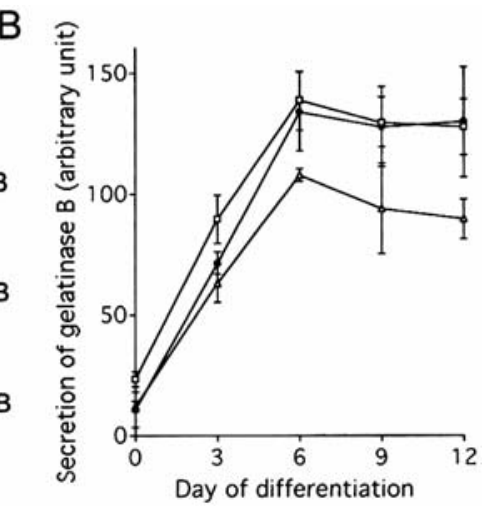

Fig. 4A, B. Gelatin substrate zymogram analysis of Rcho-1 trophoblast cells conditioned media during the differentiation under different concentrations of glucose. (A) The three gels are representative of experiments carried out in triplicate.
(28 mmol/l D-G) contained more DNA (Fig. 3A) compared with control cells, while nuclear size (Fig. 3B) was smaller. Hence, chromatin contained in the trophoblasts (Fig. 3C) exposed to high glucose was condensed compared with control trophoblasts.

Effect of high glucose on gelatinase B secretion. Gelatinase B in media conditioned by Rcho- 1 cell cultures was determined by gelatin substrate zymography, Gelatinase B secretion increased during differentiation of Rcho-1 cells until day 6 and remained stable thereafter (Fig. 4). No difference was found between trophoblasts exposed to high glucose concentration compared to control cells.

Effect of high glucose on PL-I and PL-II expression. Northern blot analysis was used to evaluate PL-I and PL-II expressions in differentiating trophoblast cells. During Rcho-1 cell differentiation, PL-I was detected first, followed by the expression of PL-II on day 9 of differentiation. The cell cultures showed an increase in PL-I and PL-II mRNA expressions during differentiation (Fig. 5); however, no difference was found when PL-I and PL-II mRNA expressions from trophoblasts exposed to a high glucose concentration were compared to control cells.
(B) Quantification of the gelatinase B expression by computerassisted scanning and densitometry with normalization to the same sample in the different gels (std). (means \pm SEM). ( $\square 6 \mathrm{mmol} / \mathrm{l} \mathrm{D}-\mathrm{G}$; $28 \mathrm{mmol} / \mathrm{l} \mathrm{D}-\mathrm{G} ; \triangle 28 \mathrm{mmol} / \mathrm{l} \mathrm{D}+\mathrm{L}-\mathrm{G})$ 


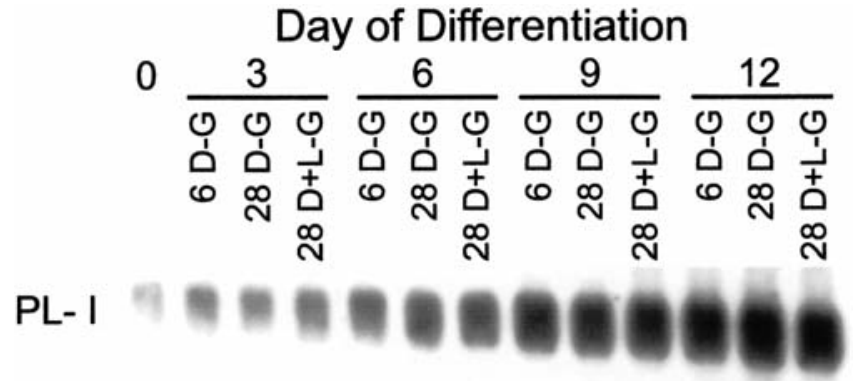

\section{PL- II}

Fig. 5. Northern Blot analysis of PL-I and PL-II expression during trophoblast cell differentiation under different concentrations of glucose. The results are representative of experiments done in triplicate

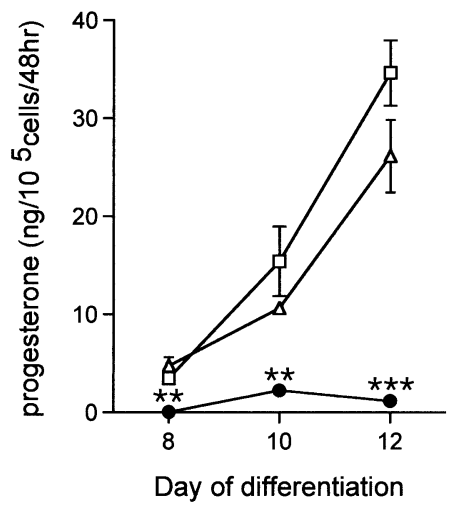

Fig. 6. Effect of different concentrations of glucose on progesterone production by Rcho-1 trophoblast cells during differentiation (means \pm SEM of three separate experiments) (** $p<0.01$; *** $p<0.001$ vs $6 \mathrm{mmol} / \mathrm{l} \mathrm{D}-\mathrm{G})(\square 6 \mathrm{mmol} / \mathrm{l} \mathrm{D}-\mathrm{G}$; $28 \mathrm{mmol} / \mathrm{l} \mathrm{D}-\mathrm{G} ; \triangle 28 \mathrm{mmol} / \mathrm{l} \mathrm{D}+\mathrm{L}-\mathrm{G})$

Effect of high glucose on progesterone secretion. Progesterone levels in culture supernatants were determined by radioimmunoassay. Progesterone was first detectable at day 6 of differentiation in Rcho-1 trophoblast cells, cultured in $6 \mathrm{mmol} / \mathrm{l} \mathrm{D}-\mathrm{G}$ and $28 \mathrm{mmol} / \mathrm{l} \mathrm{D}+\mathrm{L}-\mathrm{G}$. Progesterone secretion increased during differentiation in these cultures (Fig. 6). In cell cultures exposed to high glucose $(28 \mathrm{mmol} / \mathrm{l} \mathrm{D}-\mathrm{G})$, there was no increase in progesterone secretion; only a low level was found throughout the differentiation period (Fig. 6).

\section{Discussion}

Trophoblast cells are situated between maternal and embryonic compartments and permit the embryo to develop within the female reproductive tract. These cells develop along a multilineage differentiation pathway and their growth and differentiation are essential to the establishment and maintenance of pregnancy.
In mice and rats, the trophoblast giant cells are one of the first differentiated cells to arise in the developing embryo and are characterized by their endocrine and invasive phenotypes.

In this study, we have used the rat Rcho-1 trophoblast cell line. In vitro, when induced to differentiate, Rcho-1 trophoblast cells recapitulate all the trophoblast giant cell development characteristics, including endoreduplication, the expression of trophoblast giant cell-specific members of the placental prolactin family and the placental enzymes involved in steroidogenesis, as well as the acquisition of an invasive phenotype. The expression of differentiation specific markers is restricted to morphologically distinct giant cells. The only apparent difference observed is the failure of PL-I expression to terminate during the course of the culture as it does in vivo $[13,16,17]$. These cells have thus proven to be a valuable tool for studying the biology of trophoblast giant cells and offer a good model for elucidating the effect of high glucose concentration on different markers of trophoblast giant cell differentiation.

Different studies have established that rat and mouse blastocysts recovered from diabetic females or blastocysts cultured in vitro in a high concentration of glucose contained fewer cells, especially in the ICM and that high glucose was directly implicated in the induction of apoptosis (increase in nuclear fragmentation and chromatin degradation, BAX expression) in the ICM but not in the trophectoderm [18, 19, 20]. The absence of apoptosis induction by high glucose concentration in Rcho-1 trophoblast cells during differentiation, as in this study and in another study on three human choriocarcinoma cell lines [21], are in agreement with the observations made on blastocysts.

In rodent placenta, differentiation of trophoblast giant cells is accompanied by the endoreduplication process, continued DNA replication without cell division resulting in polyploid cells. The enlargement of cells is the consequence of this process $[22,23]$. The functional significance of endoreduplication is however unclear. The early formation of different trophoblast cell function requires rapid differentiation and, at the same time, the intensive growth. Endoreduplication resulting in polyteny is the mechanism promoting the combination of these processes [24, 25]. Rcho-1 cultures were characterized, during differentiation, by a gradual decline in the cell number per unit of surface area, by an increase in the nucleus area and by an increase in the DNA content per nucleus. These results are in agreement with other studies and suggest that Rcho- 1 cells were undergoing endoreduplication [26, 27]. The fact that some cells detach from the culture plate surface, whereas others increase in size, explains that the number of cells per unit of surface area decreased during the Rcho-1 differentiation.

When the Rcho- 1 cells were exposed to high concentration of glucose, the nuclei from these cells con- 
tained more DNA compared with control cells, while the nuclear size was smaller and the chromatin therefore was more condensed. The decline of the cell number per unit of surface area was delayed in the cells exposed to a high glucose concentration compared with the control cells. This difference was caused by a smaller nuclear size in the high glucose cells and by a smaller number of cells who detached from the culture plate. These results suggest that the high concentration of glucose in our culture media accelerated the DNA synthesis during this specific cell cycle but retarded the cellular growth. This suggests that high glucose disrupts the progression through the endocycle perhaps by impairing the cyclin/cyclindependent kinase complexes controlling each step of the endocycle [26, 27].

We used the Rcho- 1 cell line to investigate the effect of high glucose on the differentiation of trophoblast giant cells but the rat placenta is a complex organ where at least four recognizable differentiated cell phenotypes are observed: trophoblast giant cells, spongiotrophoblast cells, glycogen cells, and syncytial trophoblast cells.

The streptozotocin-induced diabetic rat has been used to study the effect of diabetes on the structure of the whole placenta $[28,29]$. In these studies, the diabetic placenta at term was characterized by a placentomegaly, large numbers of glycogen-distended cells in the basal zone and degeneration of the trophoblast cells in the labyrinth zone. DNA synthesis continued for an additional 2 to 3 days after the control placenta had completed DNA synthesis, but placental content of DNA did not differ between diabetic placentas and healthy control placentas when the DNA content was normalized to placental weight $[30,31,32,33]$.

For trophoblast cells to invade the uterine stroma, they have to degrade the components of the uterine epithelium basement membrane. Enzymes capable of degrading extracellular matrix components, such as matrix metalloproteinases (MMPs), are necessary for this invasion. The rodent trophoblast giant cells express and secrete MMPs, including MMP-9, which is also referred to as gelatinase B $[34,35,36]$. We observed that gelatinase $\mathrm{B}$ secretion increased during Rcho- 1 differentiation until day 6 and plateaued thereafter, showing that the acquisition of Rcho-1 trophoblast invasive phenotype was differentiation dependent. When gelatinase B secretion from trophoblasts exposed to a high glucose concentration was compared with the control cells, no difference was found. This result suggests indirectly that the high concentration of glucose does not influence the invasive phenotype of the giant cells. These results seem to conflict with the greater gelatinase B activity in placental tissue from patients with pre-existing diabetes mellitus as measured by another study [37]. However, we studied only the effect of high glucose on the trophoblast invasive phenotype, whilst maternal diabetes might involve other factors likely to influence gelatinase B activity. Furthermore, several studies have shown that the mechanisms by which trophoblast cells invade basement in vitro could implicate other effectors that gelatinase B [38, 39, 40]. For example studies investigating the tissue inhibitors of metalloproteinases (TIMPs) gene expression in vivo showed that concentrations of TIMP-1 mRNA peak in mouse uterus, decidua and placenta in the period covering days 6 to 10 after fertilization, the most invasive period of implantation [41].

During differentiation, trophoblast giant cells acquire an endocrine phenotype that includes the expression of members of the placental prolactin (PRL) family and the steroidogenesis [17]. The excessive or deficient release of some placental hormones could reflect an abnormal differentiation of the placenta [42]. To monitor the effect of high glucose on the endocrine phenotype, we evaluated the gene expression of two members of the PRL family, PL-I and PL-II, and the levels of progesterone in conditioned medium.

During the Rcho-1 cell differentiation, PL-I was detected first, followed by the expression of PL-II on day 9 of the differentiation and their expressions increased thereafter. In the rodent, in vivo, PL-I expression begins shortly after implantation and disappears by midgestation. PL-II expression begins after PL-I and continues until term. PL-I expression serves as an early endocrine marker of trophoblast giant cell differentiation, while PL-II expression serves as an intermediate-to-late marker [43]. The expression of PL-I on day 0 of the differentiation can be explained by few giant cells in the cultures. PL-I and PL-II coexpression by Rcho- 1 cells in vitro is in contrast to the normal development of the placenta in vivo where the coexpression is limited to approximately a $24 \mathrm{~h}$ interval during gestation. Another study [16] showed similar results in which they explained the regulation of the PL-I expression after midgestation by in vivo signals not produced by Rcho- 1 cells.

In diabetic women serum levels of hPL are reported to be normal in first trimester and normal or above normal later in pregnancy [44, 45]. Diabetic placentas are usually larger than normal placentas and contain more total RNA. These placentas could produce more $\mathrm{hPL}$ protein but the expression of hPL mRNA is not different per mg of total RNA [46]. These results are compatible with the results of our study in which we show no effect of high glucose on the mRNA expression of both PLs by differentiating Rcho- 1 cells.

It has been shown that progesterone production by rat trophoblast giant cells is implicated as a regulator of uteroplacental structure and acts directly and indirectly via its conversion to androgens [47]. Other studies speculated on the local importance of placental progesterone for maternal immunosuppression, endometrial growth and decreased uterine contractibility [48]. In our study, progesterone secretion by Rcho-1 
cells increased markedly during differentiation in control medium but failed to do so in cultures exposed to high glucose. The low level of progesterone measured in these cultures illustrates a functional and possibly structural disruption of giant trophoblast cells induced by high glucose. This might help to explain the high level of resorption observed in diabetic pregnancies. Indeed, several reports propose that the local production of progesterone acts as an immunosuppressant at the maternofoetal interface preventing the rejection of the foetal allograft $[49,50,51]$.

We have shown that high glucose concentration does not induce apoptosis in Rcho-1 cells during differentiation but disturbs some aspects of trophoblast differentiation. The cells exposed to high concentration of glucose were characterized by impaired endoreduplication process (more DNA per nucleus and smaller nuclear size) and by disturbed steroidogenesis (no increase of progesterone secretion). The invasive phenotype of the giant cells was however not influenced by the high concentration of glucose.

Acknowledgements. We are grateful to M.J. Soares for making the Rcho-1 cell line and the PL-I and PL-II probes available for us, to R. Kiss, E. Marbaix and their laboratory for their excellent technical assistance.

This study was supported by the Action de Recherche Concertée de la Direction Générale de la Recherche de la Communauté Française de Belgique (grant 96/01-96), by the Juvenile Diabetes Foundation International, by the European Foundation for the Study of Diabetes (attributed to S.P. and R.D.) and by the Fonds de la Recherche Scientifique Medicale of Belgium. L.H. is the holder of a research fellowship from FRIA.

\section{References}

1. Gardner RL, Papaioannou VE, Barton S-C (1973) Origin of the ectoplacental cone and secondary giant cells in mouse blastocysts reconstituted from isolated trophoblast and inner cell mass. J Embryol Exp Morph 30:561-572

2. Barlow P, Sherman M (1974) Cytological studies on the organization of DNA trophoblast nuclei of the mouse and the rat. Chromosoma 47:119-131

3. Bower DJ (1987) Chromosome organization in polyploid mouse trophoblast nuclei. Chromosoma 95:76-80

4. Ilgren EB (1983) Review article: control of trophoblastic growth. Placenta 4:307-328

5. Carney EW, Pridaux V, Lye SJ, Rossant J (1993) Progression expression of trophoblast-specific genes during formation of mouse trophoblast giant cells in vitro. Mol Reprod Dev 34:357-368

6. Strickland S, Richards WG (1992) Invasion of the trophoblasts. Cell 71:355-357

7. Desoye G, Shafrir E (1996) The human placenta in diabetic pregnancy. Diabetes Rev 4:70-89

8. Gewold IH, Merdian W, Warshaw JB, Enders AC (1986) Fine structural abnormalities of the placenta in diabetic rats. Diabetes 35:1254-1261

9. Leunda-Casi A, De Hertogh R, Pampfer S (2001) Control of TE differentiation by ICM-derived fibroblast growth factor-4 (FGF-4) in mouse blastocysts and possible corrective effect of FGF-4 on high D-glucose-induced trophoblast disruption in vitro. Mol Reprod Dev 60:38-46
10. Caluwaerts S, Pijnenborg R, Luyten C, Van Assche FA (2000) Growth characteristics of diabetic rat ectoplacental cones in vivo and in vitro. Diabetologia 43:939-945

11. Pampfer S, Wuu YD, Vanderheyden I, De Hertogh R (1994) In vitro study of the carry-over effect associated with early diabetic embryopathy in the rat. Diabetologia 37:855-862

12. Pampfer S, De Hertogh R (1996) Preimplantation embryopathy associated with maternal diabetes. Diabetes Rev 4:90-113

13. Peters TJ, Chapman BM, Soares MJ (1998) Trophoblast differentiation: an in vitro model for trophoblast giant cell development. In: Tuan RS, Lo CW (eds) Methods in molecular biology, 137. Humana Press, Totowa, pp 301311

14. Hamlin GP, Lu XJ, Roby KF, Soares MJ (1994) Recapitulation of the pathway for trophoblast giant cell differentiation in vitro: stage-specific expression of members of the prolactin gene family. Endocrinology 134:2390-2396

15. Dai G, Imagawa W, Liu B et al. (1996) Rcho-1 trophoblast cell placental lactogens: complementary deoxyribonucleic acids, heterologous expression, and biological activities. Endocrinology 137:5020-5027

16. Faria T, Soares MJ (1991) Trophoblast cell differentiation: establishment characterization, and modulation of a rat trophoblast cell line expressing members of the placental prolactin family. Endocrinology 129:2895-2906

17. Soares MJ, Chapman BM, Rasmussen CA, Dai G, Kamei T, Orwig KE (1996) Differentiation of trophoblast endocrine cells. Placenta 17:277-289

18. Moley KH, Chi MMY, Mueckler MM (1998) Hyperglycemia induces apoptosis in pre-implantation embryos through cell death effector pathway. Nat Med 4:1021-1024

19. Pampfer S, Vanderheyden I, McCracken JE, Vesela J, De Hertogh R (1997) Increased cell death in rat blastocysts exposed to maternal diabetes in utero and to high glucose or tumor necrosis factor- $\alpha$ in vitro. Development 124:48274836

20. Pampfer S (2000) Apoptosis in rodent peri-implantation embryos: differential susceptibility of inner cell mass and trophectoderm cell lineages. Placenta 21 [Suppl]: S3-S10

21. Weiss U, Cervar M, Schmut O, Haas J, Mauschitz R, Arikan G, Desoye G (2001) Hyperglycaemia in vitro alters the proliferation and mitochondrial activity of the choriocarcinoma cell lines BeWo, JAR and JEG-3 as models for human first-trimester trophoblast. Diabetologia 44:209219

22. Zybina EV (1970) Charasteristics of polyploidization of trophoblast cells. Tsitologiia 12:1081-1094

23. Hoffman LH, Wooding FB (1993) Giant and binucleate trophoblast cells of mammals. J Exp Zool 266:559-577

24. Zybina EV, Zybina TG (1996) Polytene chromosomes in mammalian cells. Int Rev Cytol 165:53-119

25. Varmuza S, Prideaux V, Kothary R, Rossant J (1988) Polytene chromosomes in mouse trophoblast giant cells. Development 102:127-134

26. MacAuley A, Cross J-C, Werb Z (1998) Reprogramming the cell cycle for endoreduplication in rodent trophoblast cells. Mol Biol Cell 9:795-807

27. Hattori N, Davies TC, Anson-Cartwright L, Cross JC (2000) Periodic expression of the cyclin-dependent kinase inhibitor p57kip2 in trophoblast giant cells defines a G2-like gap phase of the endocycle. Mol Biol Cell 11:1037-1045

28. Padmanabhan R, al-Zuhair A (1990) Ultrastructural studies on the placentae of streptozotocin induced maternal diabetes in the rat. Z Mikrusk Anat Forsch 104:212-230 
29. Prager R, Abramovici A, Liban E, Laron Z (1974) Histopathological changes in the placenta of streptozotocin induced diabetic rats. Diabetologia 10:89-91

30. Robinson J, Canavan J-P, El Haj A-J, Goldspink DF (1988) Maternal diabetes in rats: I. Effects on placental growth and protein turnover. Diabetes 37:1665-1670

31. Husain SM, Frost R, Mughal ZM (2001) Effect of diabetes mellitus on rat placenta cellularity. Early Hum Dev 60:207-214

32. Diamant YZ, Metzger BE, Freikel N, Shafrir E (1982) Placental lipid and glycogen content in human and experimental diabetes mellitus. Am J Obstet Gynecol 144:5-11

33. Gewold IH, Barrett C, Warshaw JB (1983) Placental growth and glycogen metabolism in streptozotocin diabetes rats. Pediatr Res 17:587-591

34. Peters TJ, Albieri A, Bevilacqua E et al. (1999) Differentiation-dependent expression of gelatinase B/matrix metalloproteinase-9 in trophoblast cells. Cell Tissue Res 295:287-296

35. Alexander CM, Hansell EJ, Behrendtsen O et al. (1996) Expression and function of matrix metalloproteinases and their inhibitors at the maternal-embryonic boundary during mouse embryo implantation. Development 122:1723-1736

36. Das SK, Yano S, Wang J, Edwards DR, Nagase H, Dey SK (1997) Expression of matrix metalloproteinases and tissue inhibitors of metalloproteinases in the mouse uterus during the peri-implantation period. Dev Genet 21:44-54

37. Pustovrh C, Jawerbaum A, Sinner D et al. (2000) Membrane-type matrix metalloproteinase- 9 activity in placental tissue from patients with pre-existing and gestational diabetes mellitus. Reprod Fertil Dev 12:269-275

38. Harvey MB, Leco KJ, Arcellana-Panlilio MY, Zhang X, Edwards DR, Schultz GA (1995) Roles of growth factors during peri-implantation development. Mol Hum Reprod 10:712-718

39. Sharma RK (1998) Mouse trophoblastic cell lines: II. Relationship between invasive potential and proteases. In Vivo 12:209-217

40. Teesalu T, Masson R, Basset P, Blasi F, Talarico D (1999) Expression of matrix metalloproteinases during murine chorioallantoic placenta maturation. Dev Dyn 214:248-258
41. Waterhouse P, Denhardt DT, Khokha R (1993) Temporal expression of tissue inhibitors of metalloproteinases in mouse reproductive tissues during gestation. Mol Reprod Dev 35:219-226

42. Reis FM, DíAntona D, Petraglia F (2002) Predictive values of hormone measurements in maternal and foetal complications of pregnancy. Endocr Rev 23:230-257

43. Yamaguchi M, Ogren L, Endo H, Soares MJ, Talamantes F (1994) Co-localization of placental lactogen-I, placental lactogen-II, and proliferin in the mouse placenta at midpregnancy. Biol Reprod 51:1188-1192

44. Selenkow HA, Varma K, Younger D, White P, Emerson K (1971) Patterns of immunoreactive human placental lactogen and chorionic gonadotropin in diabetic pregnancy. Diabetes 20:696-706

45. Pedersen JF, Sorensen S, Molsted-Pedersen L (1998) Serum levels of human placental lactogen, pregnancy-associated plasma protein A and endometrial secretory protein PP14 in first trimester of diabetic pregnancy. Acta Obstet Gynecol Scand 77:155-158

46. Mills NC, Gyves MT, Ilan J (1985) Comparisons of human placental lactogen mRNA levels from placentas of diabetics and normal term. Mol Cell Endocrinol 39:61-69

47. Soares MJ, Glasser SR (1987) Placental lactogen production and functional differentiation of rat trophoblast cells in vitro. J Reprod Fertil 79:335-341

48. Siiteri PK, Stites DP (1982) Immunological and endocrine interrelationships in pregnancy. Biol Reprod 26:1-14

49. Thellin O, Coumans B, Zorzi W, Igout A, Heinen E (2000) Tolerance to the foeto-placental 'graft': ten ways to support a child for nine months. Curr Opin Immunol 12:731737

50. Piccinni MP, Scaletti C, Maggi E, Romagnani S (2000) Role of hormone-controlled Th-1 and Th-2-type cytokines in successful pregnancy. J Neuroimmunol 109:3033

51. Ben-Zimra M, Koler M, Melamed-Book N, Arensburg J, Payne AH, Orly J (2002) Uterine and placental expression of steroidogenic genes during rodent pregnancy Mol Cell Endocrinol 187:223-231 